\title{
Digital Asthenopia: Portuguese Group of Ergophthalmology Survey
}

\author{
Astenopia Digital: Estudo do Grupo Português de \\ Ergoftalmologia
}

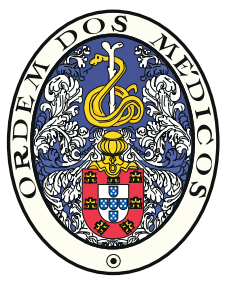

\author{
Fernando Trancoso VAZ ${ }^{1}{ }^{1}$, Susana Pinto HENRIQUES ${ }^{1}$, Diana Silveira SILVA ${ }^{1}$, Joana ROQUE${ }^{1}$, Ana Sofia LOPES ${ }^{1}$, \\ Mafalda MOTA ${ }^{1}$ \\ Acta Med Port 2019 Apr;32(4):260-265 - https://doi.org/10.20344/amp.10942
}

\section{ABSTRACT}

Introduction: Given the increasing use of electronic devices, and the increasing number of complaints with its use, we intend to evaluate the prevalence of manifestations of dry eye and ocular fatigue in a population of individuals, who use the computer daily to perform all their professional tasks, as well as to correlate these complaints with the number of hours of digital use as well as their possible improvement with behavioural measures and use of tear drops.

Material and Methods: A total of 77 individuals (154 eyes) were evaluated on two separate days with a 1-month interval. They completed two questionnaires: OSDI and PEG Eye Fatigue. An objective ocular surface assessment was performed: Schirmer test without anesthetic, DR-1a Dry Eye Monitor ${ }^{\mathrm{TM}}$, hyperemia evaluation, lacrimal break up, presence of keratitis and lesions in the conjunctiva, as well as near accommodation point and near convergence point. After the first evaluation, the subjects were divided into two groups: group A ( $<2$ hours of computer working) and group B ( $>2$ hours of computer working). Some environmental measures to reduce complaints and recommendation of use of artificial tears were explained to the latter.

Results: There was a statistically significant difference in the majority of the parameters evaluated in the group B, in relation to the morning period (group A) - tear film $(p=0.032)$, hyperemia $(p<0.001)$, BUT $(p<0.001)$, keratitis $(p<0.001)$, conjunctival lesion $(p$ $=0.002$ ) and accommodation point $(p<0.001)$. In the evaluation - one month later - there were no statistically significant differences in any of the parameters analysed in the group A, and in group B there was a decrease in most parameters at the end of that period Schirmer test $(p=0.005)$, lacrimal film $(p=0.022)$, keratitis $(p<0.001)$, conjunctival lesion $(p=0.005)$ and fatigue score $(p<0.001)$.

Discussion: It was thus possible to show the appearance of ocular fatigue and ocular surface changes with prolonged use of computers ( $>2$ hours) as well as a significant improvement in symptomatology (subjective assessment) as well as of ocular surface changes (objective evaluation) with the implementation of postural measures, regular breaks and use of lubricants. This is the first study, to the best of our knowledge, of digital asthenopia in which, in addition to the subjective evaluation, the presence of ocular surface modifications (objective assessment) were evaluated and the respective improvement with the aforementioned ergophthalmological measures were evaluated.

Conclusion: This survey highlights the increased overall level of awareness that we need to have to face the rapid and wide-scale changes driven by the emergence of digital technology and, more particularly, its impact on user's vision and posture. We concluded that the longer we use the electronic devices (more than two hours) the more severe the complaints and rates of ocular surface changes are. Environmental and ocular strategies can attenuate or even eliminate the discomfort caused by this syndrome, and increase professional performance and quality of life.

Keywords: Asthenopia; Ergonomics; Occupational Diseases; Occupational Medicine; Ophthalmology

RESUMO

Introdução: Atendendo ao uso crescente dos dispositivos eletrônicos, e o consequente aumento de queixas oftalmológicas com o seu uso, pretendemos com este estudo avaliar a prevalência de manifestações de olho seco e fadiga ocular numa população de indivíduos, de uma empresa de 'outsourcing services' e que utilizam o computador diariamente para realizar todas as suas tarefas.

Material e Métodos: Um total de 77 indivíduos (154 olhos) foram avaliados em dois dias separados por um intervalo de um mês. Completaram dois questionários: OSDI e GPE Fadiga Ocular. Foi realizada uma avaliação objetiva da superfície ocular: teste de Schirmer sem anestesia, DR-1a Dry Eye Monitor ${ }^{\mathrm{TM}}$, avaliação hiperémia, rotura lacrimal, presença de queratite e lesões da conjuntiva, bem como avaliação do ponto próximo de acomodação e ponto próximo de convergência. Após a primeira avaliação, dividiu-se a amostra em dois grupos: grupo A (<2 horas de trabalho no computador) e grupo B ( $>2$ horas de trabalho no computador). Ao grupo B foram explicadas algumas medidas ambientais para reduzir as queixas de astenopia digital e recomendou-se uso de lágrima artificial de acordo com as necessidades.

Resultados: Observou-se uma diferença estatisticamente significante na maioria dos parâmetros avaliados no grupo B, quando comparado com o grupo no período da manhã (grupo A) - filme lacrimal $(p=0,032)$, hiperémia $(p<0,001)$, BUT $(p<0,001)$, queratite $(p$ $<0,001)$, lesões da conjuntiva $(p=0,002)$ e ponto próximo de acomodação $(p<0,001)$. Na avaliação - um mês depois - não houveram diferenças estatisticamente significativas em nenhum dos parâmetros analisados no grupo $A$, enquanto que no grupo $B$ houve redução na maioria dos parâmetros ao final desse período - teste de Schirmer $(p=0,005)$, filme lacrimal $(p=0,022)$, queratite $(p<0,001)$, lesões da conjuntiva $(p=0,005)$, ponto de convergência próximo $(p=0,001)$ e score de fadiga $(p<0,001)$.

Discussão: Foi assim possível objetivar o aparecimento de fadiga ocular e alterações da superfície ocular com o uso prolongado de computadores (> 2 horas) bem como uma melhoria significativa da sintomatologia (avaliação subjetiva) e melhoria da superfície ocular (avaliação objetiva) com a implementação de medidas posturais, pausas regulares e uso de lubrificantes. Este é o primeiro estudo, tanto quanto temos conhecimento, de astenopia digital em que para além da avaliação subjetiva se avalia a presença das referidas alterações da superfície ocular e a sua melhoria com as medidas ergoftalmológicas mencionadas.

1. Serviço de Oftalmologia. Hospital Fernando Fonseca. Amadora. Portugal.

$\triangle$ Autor correspondente: Fernando Trancoso Vaz. ftrancosovaz@gmail.com

Recebido: 13 de junho de 2018 - Aceite: 20 de novembro de 2018 | Copyright @ Ordem dos Médicos 2019 
Conclusão: Este estudo realça a necessidade de estarmos alerta para as constantes e rápidas mudanças relacionadas com o uso crescente dos diferentes dispositivos digitais, bem como com o seu impacto oftalmológico e postural. Concluímos desta forma que quanto mais tempo usamos os dispositivos eletrónicos (> 2 horas), maiores são a probabilidade de desenvolver queixas e alterações da superfície ocular. As estratégias ambientais e oculares podem atenuar ou até mesmo eliminar o desconforto causado por esta síndrome e melhorar a qualidade de vida e o desempenho profissional.

Palavras-chave: Astenopia; Doenças Ocupacionais; Ergonomia; Medicina do Trabalho; Oftalmologia

\section{INTRODUCTION}

With the increasing use of electronic devices - computers, tablets, smartphones or game consoles - there is an increased effort for near vision and all this entails: increased accommodation/convergence, increased visual attention and decreased blinking with dry eye symptoms. If this effort is pronounced and/or maintained (more than two hours a day) failure of the adaptation mechanisms will occur, with exhaustion of the ocular muscles (intrinsic and extrinsic muscles) and subsequent visual fatigue (asthenopia) leading to the inability to accomplish the tasks that were intended - digital asthenopia (DA). ${ }^{1,2}$ The aim of this study is to evaluate the prevalence of manifestations of dry eye and ocular fatigue in a population of individuals who use the computer daily to perform all their tasks in an outsourcing services company called Konecta ${ }^{\mathrm{TM}}$. Another aim was to assess whether the increase in the number of hours of computer use is associated with an equal increase in ocular surface changes, as well as whether the implementation of behaviour changes and administration of tear drops - sodium hyaluronate - may attenuate those changes.

\section{MATERIAL AND METHODS}

In this study we examined employees of an outsourcing services company - Konecta ${ }^{\mathrm{TM}}$. All participants gave written informed consent; there was no financial compensation.

\section{Inclusion Criteria}

All participants had a best-corrected visual acuity of $5 / 10$ or better, and a refractive error less than 5.0 diopters of sphere and less than 3.0 diopters of cylinder. All participants were older than 18 years.

\section{Exclusion criteria}

Individuals were excluded if they had any disease and/or were taking any medication that causes dry eye syndrome (e.g. Sjogren's syndrome, anti-depressive medication, etc).

A total of 77 individuals (154 eyes) were evaluated on two separate days with a one-month interval. The two evaluations were carried out in a similar way by the same researchers and by the same order of observation.

\section{Subjective assessment}

All subjects were asked to complete two questionnaires: 1. Ocular surface disease index (OSDI) questionnaire which evaluates complaints related to ocular surface disturbances secondary to dry eye (0 to $100 \%$ scale); 2 . and a second questionnaire that addresses eye fatigue - Portuguese Group of Ergophthalmology (PGE) questionnaire (score of 0 - 16) - Tables 1 and 2.

\section{Objective assessment}

Objective assessment was performed in both eyes and

Table 1 - OSDI Questionnaire

\begin{tabular}{lccccc}
\hline $\begin{array}{l}\text { During the last week, have you noticed any } \\
\text { of the symptoms below? }\end{array}$ & Every days & $\begin{array}{c}\text { Most of } \\
\text { the days }\end{array}$ & $\begin{array}{c}\text { Half of the } \\
\text { days }\end{array}$ & Sometimes & Never \\
\hline Light sensitivity? & 4 & 3 & 2 & 1 & 0 \\
Sore eyes or watery eyes? & 4 & 3 & 2 & 1 & 0 \\
Pain / burning eyes? & 4 & 3 & 2 & 1 & 0 \\
Blurred vision? & 4 & 3 & 2 & 1 & 0 \\
Decreased vision? & 4 & 3 & 2 & 1 & 0 \\
\hline \hline During the past week, have eye problems affected & Every days & Most of & Half of the & Sometimes & Never \\
any of these tasks? & 4 & 3 & 2 & 1 & 0 \\
\hline Reading? & 4 & 3 & 2 & 1 & 0 \\
Driving at night? & 4 & 3 & 2 & 1 & 0 \\
Work at your computer, use your tablet or mobile phone? & 4 & 3 & 2 & 1 & 0 \\
Watch TV? & Every days & Most of & Half of the & Sometimes & Never \\
\hline \hline During the last week, did you experience eye discomfort & the days & days & & \\
in any of the situations? & 4 & 3 & 2 & 1 & 0 \\
\hline With wind? & 4 & 3 & 2 & 1 & 0 \\
In places with low humidity or dry weather? & 4 & 3 & 2 & 1 & 0 \\
In places with air conditioning? & \multicolumn{3}{c}{ days } \\
\hline
\end{tabular}


Table 2 - PEG Questionnaire

\begin{tabular}{|c|c|c|c|c|c|}
\hline $\begin{array}{l}\text { During the past week, have you felt any of the complaints } \\
\text { listed below? }\end{array}$ & Every days & $\begin{array}{l}\text { Most of } \\
\text { the days }\end{array}$ & $\begin{array}{l}\text { Half of the } \\
\text { days }\end{array}$ & Sometimes & Never \\
\hline Blurred vision at night, especially for reading? & 4 & 3 & 2 & 1 & 0 \\
\hline $\begin{array}{l}\text { Difficulty focusing at distance when you are long times } \\
\text { working at the computer? }\end{array}$ & 4 & 3 & 2 & 1 & 0 \\
\hline Ocular strain, pressure or headaches? & 4 & 3 & 2 & 1 & 0 \\
\hline Neck, shoulder and back pain after using computer? & 4 & 3 & 2 & 1 & 0 \\
\hline
\end{tabular}

consisted of:

1. Schirmer test without anesthetic - Normal values of test is $>15 \mathrm{~mm}$ in $<5$ minutes and abnormal if $<15 \mathrm{~mm}$ in $>$ 5 minutes;

2. DR-1a Dry Eye Monitor ${ }^{\mathrm{TM}}$ by KOWA - that allows an objective evaluation of lacrimal film through an optical interference phenomenon, and classifies the tear break test in a non-invasive manner (NI BUT). Classification of 1 to 4 , where 1 means existence of good tear film, and 4 means bad tear film);

3. Biomicroscopy with hyperemia evaluation (present or absent), lacrimal break up time (BUT) (normal if $>10$ seconds, altered if $<10$ seconds), presence of keratitis and lesions in the conjunctiva (evaluated according to the Oxford scale, from 0 to 5 , in that 0 is unchanged and 5 with many changes);

4. Accommodation and convergence - near accommodation point, measured with RAF ruler, normal or altered for age according to ruler scale, near convergence point measured in $\mathrm{cm}$ with RAF ruler, normal if $<10 \mathrm{~cm}$, altered if $>10$ $\mathrm{cm}$.

After the first evaluation, the subjects were divided into 2 groups: group A (first 34 observations, included individuals with less than 2 hours of computer working) and group $B$ (the remaining 43 observations, corresponding to the rest of population study, and that were the ones with more than 2 hours of computer working). Some environmental measures to reduce complaints were explained to the latter (change environment humidity in the air conditioner, choose right condition regarding to lights, screen positioning and pauses during computer activity - rule 20/20/20 stop - every 20 minutes during 20 seconds should look to an object 6 meters away) and therapeutic measures for dry eye reduction, with recommendation of use of artificial tears (sodium hyaluronate $0.15 \%$ - Hyabak TM Théa laboratories) whenever they have dry eye complaints.

\section{Statistical analysis}

All variables have a non-normal distribution, so we employed non-parametric statistical inference methods: 'Independent Mann-Whitney $U$ test' to study possible differences related to treatment; 'Related samples Wilcoxon Signed Rank test' to evaluate how variables change over time; 'chi-square test' to evaluate how the variables change from morning vs. afternoon in the same day). Since we employed non-parametric statistics, we cannot calculate averages and standard deviations. To describe the population sample, we used median (equivalent to the parametric mean) and IQR (Interquartile range, equivalent to the parametric standard deviation). Statistical analyses were performed using commercially available software (SPSS Statistics 24 IBM). Statistical significance was defined at $p$ $<0.05$.

\section{RESULTS}

A total of 77 individuals (154 eyes) were observed, with a median age of 34 years and 59 were females (77\%). More than half $(58 \%)$ of individuals wear glasses and $12 \%$ wear monthly contact lenses.

In the first evaluation, the median OSDI score is 29 and the ocular fatigue score is 7 . Only $8 \%$ of subjects had alterations in the Schirmer test, $25 \%$ had alterations in the BUT, $18 \%$ had hyperemia. $44 \%$ had accommodation changes and $12 \%$ had convergence disabilities. There was a statistically significant difference in the majority of the parameters evaluated in the afternoon (group $B$ ) compared with the morning period (group A) - tear film $(p=0.032)$, hyperemia $(p<0.001)$, BUT $(p<0.001)$, keratitis $(p<0.001)$, conjunctival lesion $(p=0.002)$ and near accommodation point $(p<$ $0.001)$. There was no statistically significant difference in the Schirmer test $(p=0.303)$, near convergence point $(p=$ $0.440)$ and ocular fatigue $(p=0.567)$ - Table 3 .

In the second evaluation - one month later - there were no statistically significant differences in any of the parameters analysed in the group A - without behavioural intervention - Table 4. In the group that received a leaflet with the recommendations described above - group B - most clinical parameters improved at the end of that period - Shirmer test $(p=0.005)$, lacrimal film $(p=0.022)$, keratitis $(p<0.001)$, conjunctival lesion $(p=0.005)$, near convergence point $(p=$ $0.001)$ and fatigue score $(p<0.001)$. However, there were no statistically significant changes in near accommodation point $(p=0.056)$ and hyperemia $(p=0.038)$ or OSDI score $(p=0.492)-$ Table 5 .

\section{DISCUSSION}

To the best of our knowledge this is the first study of digital asthenopia that includes both a subjective (questionnaire) as well as an objective assessment. Computer vision syndrome, or digital asthenopia, is a transient and nonspecific disturbance related with the use of digital devices. All these gagdets represent a great step forward, since they dramatically increase possibilities for exchange, interaction and cooperation, and facilitate access to knowledge. 
Table 3 - Data from the first assessment comparing group A versus group B

\begin{tabular}{lccc}
\hline First assessment & Group A & Group B & Test \\
\hline OSDI & $35 / 100$ & $27 / 100$ & $p=0.440$ \\
PGE eye fatigue & $7 / 16$ & $7 / 16$ & $p=0.567$ \\
Schirmer test & $6 \%$ & $10 \%$ & $p=0.303$ \\
Tear film & $\mathbf{2 . 7 1 \pm 0 . 6 2}$ & $\mathbf{2 . 9 7 \pm 0 . 8 1}$ & $p=0.032$ \\
Hyperemia & $6 \%$ & $29 \%$ & $p<0.001$ \\
BUT test & $7 \%$ & $42 \%$ & $p<0.001$ \\
Keratitis & $\mathbf{0 . 0 3} \pm \mathbf{1 . 7 0}$ & $\mathbf{0 . 7 9} \pm \mathbf{0 . 9 7}$ & $p<0.001$ \\
Conjunctiva & $\mathbf{0 . 0 3 \pm 1 . 7 0}$ & $\mathbf{0 . 3 7 \pm 0 . 7 9}$ & $p=0.002$ \\
Accommodation & $77 \%$ & $20 \%$ & $p<0.001$ \\
Convergence & $12 \%$ & $12 \%$ & $p=0.570$ \\
\hline
\end{tabular}

Table 4 - No significant differences in Group A when comparing initial evaluation with evaluation after one month

\begin{tabular}{lccc}
\hline Group A & 1 $^{\text {st }}$ Assessment & 2 $^{\text {nd }}$ Assessment & Test \\
\hline OSDI & $35 / 100$ & $33 / 100$ & $p=0.492$ \\
PGE eye fatigue & $7 / 16$ & $6.5 / 16$ & $p=0.257$ \\
Schirmer test & $6.0 \%$ & $6.8 \%$ & $p=0.082$ \\
Tear film & $2.71 \pm 0.62$ & $2.57+-0.70$ & $p=0.119$ \\
Hyperemia & $6.0 \%$ & $6.8 \%$ & $p=0.842$ \\
BUT test & $7.0 \%$ & $5.8 \%$ & $p=0.066$ \\
Keratitis & $0.03 \pm 1.70$ & $0.11 \pm 0.32$ & $p=0.083$ \\
Conjunctiva & $0.03 \pm 1.70$ & $0.07+-0.26$ & $p=0.317$ \\
Accommodation & $77.0 \%$ & $50.0 \%$ & $p=0.004$ \\
Convergence & $12.0 \%$ & $45.5 \%$ & $p<0.001$ \\
\hline
\end{tabular}

Table 5 - Differences in Group B initial evaluation and after one month

\begin{tabular}{lccc}
\hline Group B & 1 $^{\text {st }}$ Assessment & 2 $^{\text {nd }}$ Assessment & Test \\
\hline OSDI & $27 / 100$ & $23 / 100$ & $p=0.492$ \\
PGE eye fatigue & $7 / 16$ & $4.6 / 16$ & $p<0.001$ \\
Schirmer test & $10 \%$ & $0 \%$ & $p=0.005$ \\
Tear film & $2.97 \pm 0.81$ & $2.74 \pm 0.74$ & $p=0.022$ \\
Hyperemia & $29 \%$ & $13 \%$ & $p=0.038$ \\
BUT test & $42 \%$ & $0 \%$ & $p<0.001$ \\
Keratitis & $0.79 \pm 0.97$ & $0.09 \pm 0.29$ & $p<0.001$ \\
Conjunctiva & $0.37 \pm 0.79$ & $0.04 \pm 0.21$ & $p=0.005$ \\
Accommodation & $20 \%$ & $35 \%$ & $p=0.056$ \\
Convergence & $12 \%$ & $13 \%$ & $p=0.889$ \\
\hline
\end{tabular}

However, they cause this multifactorial syndrome, which is responsible for several ocular and visual symptoms associated with the varied and intense use of digital displays, whether for recreational purposes or in a work/schooling context. These devices have become an accepted part of everyday life, irrespective of age, social class or geographical area. ${ }^{3-5}$ A North American study estimates that $90 \%$ of the 70 million American workers who use these devices do it more than 2 hours a day, and $60 \%$ more than 5 hours a day. One child out of four is exposed to screens over three hours a day. In the same study, it is estimated that approximately $65 \%$ of Americans citizens suffer from this syndrome to some degre. ${ }^{6}$ The increasingly widespread use of these devices to perform an increasing number of everyday activities makes this syndrome clinically and statistically very relevant. This growing trend is not likely to be reversed any time soon, nor are the related ophthalmic problems. Clinically, this syndrome is manifested by five groups of symptoms, ${ }^{7-9}$ which are sometimes vague, or difficult to describe, and those who suffer from this disorder are often not aware of them:

1. Symptoms related to astenopia: eye strain, tired or sore eyes, headaches. The accommodative effort, during short distances activities, may be responsible for the development of myopia which is temporary (due to excessive accommodation - pseudo myopia), in fact the incidence of 
myopia in these users does not appear to be increasing ${ }^{10}$;

2. Symptoms related to dry eye: foreign body sensation, eye burning, red eye, tearing, contact lens intolerance ${ }^{11-14}$;

3. Symptoms related to visual fatigue: distance blur after near work, slowness in focusing for all distances and diplopia (less frequent and usually associated with a phoria - extrinsic muscle insufficiency);

4. Muscular symptoms: neck and back ache are quite common in computer-using patients, and can often be due to inappropriate location of the display or inappropriate spectacle correction of presbyopia ${ }^{15-18 ;}$

5. Psychological symptoms: Even more pervasive video gaming is associated with player immersion and strong screen flicker. These two situations can eventually stimulate systemic and endocrine functions, resulting in elevated cortisol levels. Overexposure to blue light emitted by screens can disrupt the secretion of melatonin and thus affect quality of sleep. The main repercussions have been found to affect: sleep, behavior, mood, motivation and learning.

From the assessment we made on the first day, and when comparing the objective evaluation between the morning group versus the afternoon group, we found more manifestations of dry eye and ocular fatigue in this last group. That probably reflects the longer time of screen exposure. The longer and more frequently one uses digital devices, the more one is affected by ocular or physical symptoms.

Despite the vague nature of its symptoms, asthenopia can be reduced or even eliminated if the syndrome is diagnosed and treated. We have to adopt a multidisciplinary approach to reduce asthenopia complaints. In the treatment of DA it is relevant to consider the correction of associated ocular conditions, as well as the patient's education regarding strategies to adapt to their usual environment.

\section{Ocular strategies}

Detection and correction, in an ophthalmology appointment, of any refractive error, binocular vision and accommodation problems as well as dry eye is important. Sometimes the use of special lenses with low-magnification in the bottom part of the lens, with concomitant use of filters for the blue light as well as antireflective filters is thought to be associated with a reduction in the patient's complaints. ${ }^{19} \mathrm{In}$ patients with presbyopia, use of progressive lenses with an extended channel for intermediate viewing, or occupational lenses, in order to correct close and intermediate distances is needed. Advising work breaks is also important: regular pauses looking for far objects while working with these devices, is related to a decrease of fatigue symptomatology, as it allows relaxation of the circular fibers of the ciliary muscle as well as an increase in blinking. The 20-20-20 rule states that you should pause every 20 minutes during 20 seconds looking at a distance of 20 feet $(6 \mathrm{~m})$. It is also advisable to provide artificial tears to be used as needed.

\section{Environmental strategies}

Avoid dry environments, strong air flows, dust or fumes. Regulate the temperature and airflow of air conditioning and heating systems. Constant luminous intensity throughout the visual field eliminating glare from lights. ${ }^{20}$ The computer display should be at $35-40 \mathrm{~cm}$ distance from the user's eye, and the top of the display should be near eye level, if less than 40 years old or higher than 40 years old and if occupational glasses are used, or a little lower if progressive glasses are used.21,22 The size and contrast of characters on a computer screen must meet criteria established by the visual performance of the normal eye. Upright posture while maintaining the normal convex curvature of the lower spine can be important to ensure long term comfort, and arms should be supported by chair arm rests to avoid tension across the shoulders.

The reduced clinical complaints and the objective results after one month, in group $B$, in which we intervene (environmental measures, pauses and use of lubricants) demonstrates their importance in the prevention and treatment of this syndrome.

\section{CONCLUSION}

This Portuguese survey highlights the increased overall level of awareness that we need to have to face the rapid and wide-scale changes driven by the emergence of digital technology and, more particularly, its impact on user's vision and posture. There are solutions today to reduce it but they depend on its cause. We concluded that the longer we use electronic devices (more than two hours) the more severe the complaints and ocular surface changes rates are. We don't have to cut out all screen time, but a few changes to the way we use our devices can ease the strain to our eyes. The environmental and ocular strategies can attenuate or even eliminate the discomfort caused by this syndrome, and increase professional performance and quality of life. Consumer awareness campaigns are an important means of highlighting the risks and symptoms related to the use of digital displays, and offer the opportunity to stress the need for regular ophthalmologic exams.

\section{ACKNOWLEDGEMENTS}

To our Ortopthists: Sandra Gonçalves, Patríca Condado and Herlander Marques, for their participation and effort. To our young students: Marta Vaz Gomes and Nuno Trancoso Vaz, for their participation in the bureaucratic organization of the study.

To Konecta ${ }^{\circledR}$ company, in particular to its general director in Portugal, Alfonso Maldonado, for the availability and kindness in letting us perform this study at its Restelo's facilities, but above all for the courage to evaluate its employees. As he always told us, "it is important to see if there is any problem so we can improve our working conditions". Praiseworthy and very constructive attitude.

To Théa Laboratoires (Portugal), and in particular to its director, João Caldas, for all his enthusiasm, effort and commitment to this project and to make it go forward despite some setbacks.

To J. Cotta ${ }^{\circledR}$ Company for providing us, at no cost, all the ophthalmologic equipment we needed it, including 
the KOWA ${ }^{\circledR}$ Dry Eye Monitor DR-1a Dry Eye Monitor.

\section{CONFLICTS OF INTEREST}

The authors have no conflicts of interest to declare.

\section{PROTECTION OF HUMANS AND ANIMALS}

The authors declare that all procedures followed the Helsinki Declaration of the World Medical Association.

\section{REFERENCES}

1. Henriques S, Lopes AS, Roque J, Gonçalves S, Condado P, Vaz-Gomes M, et al. Astenopia digital - estudo Konecta. Perguntas e Respostas em Ergoftalmologia. 2018;38:4.

2. Silveira e Silva D, Trancoso Vaz F. O que é a síndrome de fadiga ocular ao computador ou astenopia digital? Perguntas e Respostas em Ergoftalmologia. 2018;3437.

3. Blehm C, Vishnu S, Khattak A, Mitra S, Yee RW. Computer vision syndrome: a review. Survey of Ophthalmology. 2005;50:253-62.

4. Rosenfield M. Computer vision syndrome: a review of ocular causes and potential treatments.Ophthalmic Physiol Opt. 2011;31:502-15.

5. Gentil R, Okawa C, Carvalho C, Barison D. Computer vision syndrome. Science in Health. 2011;2:64-6.

6. Hindsight is 20/20/20: Protect your eyes from digital devices. Washington, USA: The Vision Council. 2015.

7. The International Dry Eye Workshop. Ocul Surf. 2007;5:63-204.

8. Collier J, Rosenfield M. Accommodation and convergence during sustained computer work. Optometry. 2011;82:434-40.

9. Mutti D, Zadnik K. Is computer use a risk factor for myopia? J Am Optom Assoc. 1996;67:521-30.

10. Smita Aarwal S, Gel D, Sharma A. Evaluation of the factors which contribute to the ocular complaints in computer users. J Clin Diag Res. 2013;7:331-5.

11. Garcia Molina V. Blue light: from scientific evidence to patient care. Points de Vue, International Review of Ophthalmic Optics. 2016. [accessed 2017 Jul 12 ]. Available from: www.pointsdevue.com.

12. Isono H, Kumar A, Kamimura T, Noguchi $Y$, Yaguchi $H$. The effect of blue light on visual fatigue when eedding on led-backlit tablets LCD. Tokyo: Tokyo Denki University; 2013. p. 2-9L.

\section{DATA CONFIDENTIALITY}

The authors declare having followed the protocols in use at their working center regarding participants' data publication and conidentiality. All procedures followed the Helsinki Declaration of the World Medical Association.

\section{FUNDING SOURCES}

This project was supported by Théa Laboratoires and by J. Cotta, as described in the acknowledgements.

13. Siegenthaler E, Bochud $Y$, Bergamin P, Wurtz P. Reading on Lcds vs e-ink displays: effects on fatigue and visual strain. Ophthalmic Physiol Opt. 2012;32:367-74

14. Eldeeb R, Sreedharan J, Gopal K. Computer use and vision-related problems among university students in Ajman, Arab Emirate $\mathrm{N}$ Shantakumari. Ann Med Health Sci Res. 2014;4:258-63.

15. Ritto I. Onde devo colocar o meu computador? Perguntas e Respostas em Ergoftalmologia. 2018;42-5.

16. Lodin C, Forsman M, Richter H. Eye and neck/shoulder-discomfort during visually demanding experimental near work. Work. 2012;338892.

17. Zetterberg $\mathrm{C}$, Forsman $\mathrm{M}$, Richter HO. Effects of visually demanding near work on trapezius muscle activity. J Electrom Kinesiol. 2013;23:1190-8.

18. Brandt LP, Andersen JH, Lassen CF, Kryger A, Overgaard E, Vilstrup I, et al. Neck and shoulder symptoms and disorders among Danish computer workers. Scand J Work Environ Health. 2004;30:399-409.

19. Bívar F, Santos A, Alves da Silva O. Os monitores fazem mal aos olhos? Oftalmologia. 2005;29:29-36.

20. Lamphar HA. Ergoftalmologia: analisis de los factores que inciden en la astenopia de los trabajadores de inspeccion visual en la industria electrónica de ciudad de Juárez. Ciencia Trabajo. 2006;21:135-40.

21. Turville K, Psihogios J, Ulmer T, Mirka G. The effects of video display terminal height on the operador: a comparison of the $15^{\circ}$ and $40^{\circ}$ recommendations. Applied Ergonomics. 1998;29;239-46.

22. Straker L, Mekhora K. An evaluation of visual display unit placement by electromyography, posture, discomfort and preference. Inter J Indust Ergonomics. 2000;26:389-98. 